\title{
'Her flesh must serve you': Gender, Commerce and the New World in Fletcher's and Massinger's The Sea Voyage and Massinger's The City Madam
}

\author{
Claire Jowitt
}

This essay examines the complex interaction between gender and the New World in two early-to-mid-seventeenth-century comedies, Fletcher's and Massinger's collaborative The Sea Voyage (1622) and Massinger's single-authored The City Madam (1632).' Both texts engage with the Virginian enterprise and the troubled history of the Jamestown venture. Indeed, characters' attitudes towards, and behaviour in, colonial situations are used to measure their conformity to expected gender behaviour. Furthermore, 1 argue that characters' gender performance specifically their attitude to sexual commerce - figures as a metaphor for a larger set of commercial relations with the New World. The men and women in these

1 John Fletcher and Philip Massinger, The Sea Voyage, in Three Renaissance Travel Plays, ed. Anthony Рап (Manchester: Manchester University Press, 1995), pp. 135-216; Philip Massinger, The City Madam, ed. Cynus Hoy (London: Edward Arnold, 1964). All references are to these editions. For a detailed discussion of this text see Martin Butler, 'Massinger's The City Madum and the Caroline Audicnce', Renaissance Drama, 13 (1982), pp. 157187; Michae! Neill, '“The Tongues of Angels": Charity and the Social Order in The City Madam', in Philip Massinger: A Critical Reassessment, ed. Douglas Howard (Cambridge: Cambridge University Press, 1985). pp. 193-220; Ira Clark, The Moral Art of Philip Massinger (London \& Toronto: Associated Universities Press, 1993), pp. 41-49. 
dramas are represented as conforming to, or deviating from, a male or female ideal in terms of sexual congress, which, in tum, acts as a yardstick for their moral, social and cultural worth. The correct management of appetite is crucial in determining commercial/sexual/social position and success. More particularly, as we shall see, Fletcher and Massinger use their characters' attitudes to native inhabitants - particularly the prospect of miscegenation or the adoption of savage, native pattems of behaviour - as especially significant indices of their relationship with the dominant social order.

Though the action of The City Madam takes place in Renaissance London, and that of The Sea Voyage is solely located on castaway islands, both plays engage with the Virginia project. Massinger's The City Madam draws explicitly on a Virginian context in the second half of the play, since the profligate and proud Lady Frugal and her two daughters, Mary and Ann, are threatened with a violent, sacrificial death in Virginia because they transgress accepted class and gender behaviour. Like The Tempest, the play with which The Sea Voyage is most frequently compared, Fletcher's and Massinger's text is less obvious in its engagement with Virginia. ${ }^{2}$ Nevertheless, The Sea Voyage is full of the most potent but unsettling images culled from recent English explorers' and settlers' accounts: Amazonian women, endemic starvation, fomenting rebellion, European rivalry, and, of course, easy riches represented by caskets of jewels strewn lavishly across the colonial landscape. Although the text's most recent editor, Anthony Parr, suggests that 'the very abundance of analogy ... refutes any attempt to tie it exclusively to a particular place or venture', the presence of European women on board Portuguese and French ships is significant in locating this play within a Western rather than an Eastern context, since the former was concerned with permanent settlement and the latter with temporary trading posts." Women

2 The colonial context for The Tempest has been extensively explored in recent years. Sce, for instance, Ronald Takaki, 'The "Tempest" in the Wilderness', in Shakespeare, The Tempest, ed. Gerald Graff and James Phelan (Boston: Bedford, 2000), pp. 14l-172; and, most recently, see Peter Hulme and William $\mathrm{H}$. Sherman (eds.). The Tempest and Its Travels (London: Reaktion, 2000). For an alternatc - non-colonial - reading see Douglas L. Peterson, Time, Tide and Tempest: A Study of Shakespeare's Romances (San Marino, California: Huntington Library Publications, 1973). pp. 2 14-249.

3 Part, "Introduction', Three Renaissance Travel Plays, p. 22. On the differences between Eastern and Western European colonjal ambitions see A. D. Innes, The Maritime and Colonial Expansion of England under the Stuarts. 1603-1714 (London: Sampson Low, 1931), pp. 81-124; Jerry Brotton, Trading Territories: Mapping the Eariy Modern World (London: Reaktion Books, 1997). 
passengers indicate that these voyages were likely to be concerned with Western plantation and settlement. Aminta is on board ship through coercion, but Rosellia and her women were shipwrecked while on an expedition 'to seek new fortunes in an unknown world' (V.iv.31) in the 'happy islands', in other words the 'Fortunate Isles' or the Canaries (V.ii.88). Though Aminta is blamed for the storm that wrecks the ship in the opening scene of The Sea Voyage (signalling that tension is still generated by women invading the traditionally male environs of seafaring), the presence of European women on ships and in colonies offers London playgoers at the Blackfriars theatre in 1622 a fairly accurate representation of the demography of the Virginia colony. As the purpose of travel shifted from male-dominated exploration and fortune-seeking to permanent settlement, women joined the migrations to North America in numbers. ${ }^{4}$ During the seventeenth century, the ratio of white males to females emigrating to North America never went below three-to-one (and was frequently much higher) and the Virginia company was advertising heavily for women settlers to marry male colonists in this period. ${ }^{5}$ Yet, despite this demographic imbalance, European women were becoming a significant presence in the colonies and The Sea Voyage reflects beliefs about the importance of women for the maintenance of well-being in the colonies of the early $1620 \mathrm{~s} .{ }^{6}$

The Virginian plot of The City Madam does not appear until late in this play and it is clear from the casual way in which Lady Frugal and her daughters are mentioned as potential Virginian colonists that in the ten years since The Sea Voyage was written, the female population of the colony had increased further. The plot mainiy concerns the domestic arrangements of the Frugal family. The women of the family, despite belonging to the prosperous city merchant classes, dress and behave fas more excessively than even the most luxurious of the nobility, and demand 'absolute sovereignty' for women (II.ii.85). They assert their power over Luke, the supposedly repentant wastrel brother of Sir John Frugal,

4 Sce Sara M. Evans, Born for Liberty: A History of Women in America (New York: Free Press, 1989), pp. 7-45; Robert V. Wells, The Population of the British Colonies in America before 1776 (Princeton: Princeton University Press, 1975).

5 Parr. 'Introduction', p. 27; Sylvia R. Frey and Marion J. Morton New World, New Roles: A Documentary History of Women in Pre-Industrial America (New York: Greenwood Press, 1986).

6 Evans, Born for Liberty, pp. 25-26; see also David R. Ranson, 'Wives for Virginia, 162l', William and Mary Quarterly, 3rd scries, 48 (1991), pp. 3-18. 
for example, by treating him as their 'slave' (I.i. 102), forcing him to run demeaning errands. Encouraged by their mother, the daughters also demand mastery over prospective husbands (II.ii.]65-167). Indeed as a result of their overweening pride, Lady Frugal's husband, Sir John, feels disempowered by his opinionated and unruly family: "What's wealth, accompanied / With disobedience in a wife and children? / My heart will break' (Il.iii.46-48). He also distrusts his prodigal brother Luke's conversion to virtue and determines to discover whether 'he prove / true gold in the touch' (II.i.I58-159). Hence, like the Duke in Measure for Measure, Sir John pretends to retreat to a monastery whilst, in fact, he continues to orchestrate events from the sidelines.

Sir John's plot to test Luke involves him masquerading as a native American sachem, or king, whom he had previously sent to London to be converted to Christianity. Sir John tells his brother that in fact the group of native Americans are devil worshippers and that their real reason for being in Britain is to procure three British women, 'Two Christian virgins ... and a third Married' 'that with their pure blood/Might dye his horid altars' (V.i.36-39). This representation of native Americans as devil worshippers is one that frequently appeared in Virginian travel literature and propaganda: Captain John Smith, for example, asserted in 1624 'their chiefe God they worship is the Devill. Him they call Okee, and serve him more of feare than love'. Hence the text represents Sir John, like Massinger's Puritan patron Lord Pembroke, as philanthropically concerned to forward in his New World interactions the ethos of virtuous conversion as well as trade. We have here an example of what Stephen Greenblatt has termed 'Christian imperialism'; Sir John is involved in the exchange of New World riches for Old World Christianity. ${ }^{8}$ Indeed the Virginia Company proclaimed in 1610 that their first goal was to "preach and baptize into the Christian Religion and by propagation of the Gospell, to recover out of the armes of the Divell, a number of poore and miserable soules, wrapt up unto death, in almost invincible ignorance ${ }^{*}$.

There is a significant distance, however, between the ideal and the real in terms of the text's representation of life in Virginia. Despite claiming authorisation by divine mandate to spread God's word, colonists' sexual

7 Captain John Smith, The General History of Virginia (London, 1624), p. 35.

8 Stephen Greenblatt, Morvellous Possessions: The Wonder of the New World (Oxford: Clarendon Press, 1988), pp. 70-72.

9 Quoted by Butler, 'Massinger's The City Modam', p. 179. 
behaviour is satirically represented as promiscuous in this text. The native Americans' mission to Britain is necessary only because female virginity 'was not to be purchas'd' in the New World (V.i.9). Female virginity, like any other form of goods, is represented as a commercial property whose price becomes inflated when demand exceeds supply. Furthermore the reputation of the colony more generally is clearly not a positive one. When Luke deviously offers to send his sister-in-law and nieces to Virginja to be 'Queens in another climate' (V.i.98), the women protest at the thought of keeping company with:

ANNE. Condemn'd wretches,

Forfetited to the law.

MARY. Strumpets and bawds,

For the abomination of their life,

Spew'd out of their country.

The women here refer to the fact that many of the colony's settlers were either convicts, or those unemployed or underemployed in Britain; hence Virginian society was not thought likely to be a law-abiding one by the inhabitants of seventeenth-century London. Indeed, stories about Virginian malpractice and licentiousness were common: for example, in 1609 some 'unruly youths' stowed away on the same vessels that deposited them in Jamestown, after swearing an oath to denigrate the colony on their retum to England: they circulated in all places ... (to colour their owne misbehaviour, and the cause of their retum with some pretence) most vile and scandalous reports, both from the countrey it selfe and the carriage of businesse there'. ${ }^{10}$

Virginia is represented in contradictory ways in The City Madam. Luke and the disguised Sir John try to argue to the women that it is a place in which all their ambitions will be fulfilled:

10 Quoted by Nicholas Canny, 'The Permissive Frontier: The Problem of Social Control in Ireland and Virginia 1550-1650', in The Westward Enterprise: English Activities in Ireland, the Atlantic; and America, 1480-1650, ed. K. R. Andrews et al. (Livetpool: Liverpool University Press, 1978), pp. 17-45 (p. 29). 
SIR MAURICE. You shall be ador'd there

As goddesses.

SIR JOHN. Your litters made of gold

Supported by your vassals, proud to bear

The burden on their shoulders.

PLENTY. Pomp and ease,

With delicates that Europe never knew,

Like pages shall wait on you.

(V.i.118-123)

But such an image is a ruse, a fantasy, and a dream. Virginia is, more accurately, we are encouraged to believe, a dumping ground for the socially undesirable elements of British society. It is a place of debauched licentiousness and irreligion since it is populated by those excluded from Britain and devil-worshipping natives. As such it is used by men in this text as an imaginary site in which to contain, punish and murder unruly women. The fantasy of sending the women to their death in Virginia is, importantly, one that is created by their husband and father. It is a scheme that is hatched by the moral centre of the play, Sir John, not the text's villain, Luke (though of course he warmly embraces it). In this text, then, Virginia is represented as a depraved and dystopic society: it is used as a kind of spectre to deter women from socially unacceptable behaviour. Like the branks, or scold's bridle, the threat of life in Virginia will school all but the most depraved and unuly woman into docility."

The complexities inherent in Massinger's representation of Virginia in The City Madam find their precedent in Fletcher's and Massinger's earlier drama, The Sea Vovage which also sees sexuality - specifically reproductive capacity in terms of commercial value. Concemed with the shipwreck of a band of French privateers on castaway islands, who discover the surviving inhabitants of a previous Portuguese venture where the men and women have been marooned separately, The Sea Voyage satirises both the behaviour and roles of European men and women. Through much of the play the colonists are separated from each other in small, single sex groups and the plot focuses on the establishment of cordial relations between these factionalised groups as they discover that they

11 Sec D. E. Underdown, 'The Taming of the Scold: The Enforcement of Patriarchal Authority in Early Modem England', in A. Fletcher and J. Stevenson (eds.), Order and Disorder in Early Modern England (Cambridge: Cambridge University Press, 1985), pp. 116-136. 
need each other to survive. The text draws a distinction between resources needed for immediate survival - food and water - and those necessary for medium and long-term colonisation - children to be new generations of settlers. Initially, each group possesses different resources and, importantly, no group possesses everything necessary to ensure their long-term survival. The Portuguese women inhabit fertile terrain and hence have food and water but they cannot reproduce without men; the other two groups inhabit a barren wasteland and are about to starve. Though the mixed-sex French group originally possessed a boat - an escape route from the island - they swiftly lose it to the starving but uselessly treasure-laden Portuguese men. Indeed colonists' greed for easy riches is satirised in Act I, scene iii where Sebastian reveals that gold lust was the downfall of the earlier Portuguese expedition: 'This gold was the overthrow of my happiness' (175). Furthermore, the Frenchmen, at the sight of all the 'gold and jewels' (I62) descend to violent squabbling concerning their portions and abandon their boat. Consequently, the starving Portuguese steal their ship leaving the French, miserable and without food, possessing only 'damned enticing gold' (221) and jewels to eat.

The gender of the members of these separate groups is important, since, in order to establish a secure colony with a future, there needs to be sexual commerce to produce future generations. Gender, specifically reproductive capacity, is just as much as a resource as food or any other commodity necessary for the maintenance of life. Hence, the plot of The Sea Voyage follows the haphazard and hostile interaction between these separate colonies until, finally, an understanding between the groups is achieved which enables them to pool resources. Between the separate factions there are enough resources to ensure a sustainable lifestyle, but the play documents the misunderstandings and inaccurate beliefs between groups that mean, until the conclusion of the play, no group is prepared to foster cordial relations. For much of the play, each group acts as though it is in competition with the others rather than working in tandem for the mutual benefit of all.

The romance of the play's central characters, Captain Albert and Aminta, explicitly addresses the issue of establishing secure and lasting relationships through the maintenance of gender-appropriate behaviour in colonial contexts. Albert's masculinity comes under scrutiny after he is shipwrecked on the barren terrain. When Aminta appears to be in a better condition than he does ('my weakness / Is not for what I suffer in myself / But to imagine what you endure'), Albert immediately becomes concerned about his masculinity: 
Do not add

To my afflictions by your tender pities.

Sure we have changed sexes: you bear calamity

With a fortitude would become a man;

I like a weak girl suffer.

In the beginning of this scene it is clear that, for Albert at least, gender roles have been reversed since Aminta appears brave and solicitous, as Albert lies supine and helpless. The next event in the scene is also significant since Aminta decides to "play the surgeon' (II.i.15) - a masculine role - and bind his gaping (female) wounds. She does this by cutting off her hair and using the "pure locks' (II.i.19) for the purpose. By cutting her hair, Aminta removes a culturally significant indicator of gender. Indeed, the contemporaneous pamphlets Hic Mulier and Haec Vir emphasise that women's appropriation of masculine hairstyles is one of the key factors in the troubling and fashionable obfuscation between genders. ${ }^{12}$ The woodcut illustration on the title-page of Hic Mulier, for example, shows the toilet of a fashionable lady, a 'monstrous' 'man-woman', as her servant, brandishing a sexually meaningful open pair of scissors asks 'Mistris, will you be trim' $\mathrm{d}$ or truss' $\mathrm{d}$ ?' ${ }^{\prime 3}$ The pamphlet continues to make the connection between short hair and transgression; masculine-women have given up 'the glory of a faire large hayre, to the shame of most ruffianly short lockes' and such behaviour is indicative of sexual depravity as 'womens modestie' has been transformed to "apish incivilitie'. ${ }^{4}$

The rest of this scene in The Sea Voyage, however, attempts to restore the hero and heroine to more traditional gender roles. Albert, revived by Aminta's ministrations, becomes appropriately masculine once more as he kisses Aminta and declaims against Nature for her cruelty in making 'a virgin' (Aminta) "pine for hunger' (11.i.35-50). The play's repeated emphasis on the connection between appetite for food and sexual desire is focused on here since Aminta's kisses represent a 'banquet' to the starving Albert. Though Aminta asserts she 'could eat to bear you company' - that is have sex with him - the real starvation they

12 Anon., Hic Mulier (London) 1620; Anon., Haec Vir (London) 1620.

13 Hic Mulier, A2r.

14 Hic Mulier, A4v. It is also noticeable that Scbastian and Nicusa's excessive facial hair ('They have horse-tails growing to 'em, Goodly long manes') makes them 'seem monsters' $(1$. iii. 98,108$)$. Men as much as women can seem 'monstrous' and animalistic. 
face means that for now she must remain a virgin. At this point the intimate scene is interrupted by the sound of 'free hunters' music' and Albert becomes determined to discover 'Another island ... the seat of fortunate men' from where the noise emanates. Though mistaken in his belief that the hunters he hears are male (they are, in fact, Amazons) Albert appears for the rest of the scene in traditional heroic male guise, comforting the now 'wretched' Aminta who fears being left alone. The sound of, he believes, males hunting for food, revives his own masculinity as he becomes determined to secure some of the food for Aminta. As to a child, he cajoles her with imaginary scenarios and the promise of good 'dreams':

when that sleep

Deceives your hunger with imagined food

Think you have sent me for discovery

Of some most fortunate continent, yet unknown,

Which you are to be queen of.

Noticeably, Fletcher represents the retreat into fantasy to sustain colonial ambitions as only suitable for the female Aminta; Albert promises to resist the allure of such pleasures: 'I would not eat nor sleep till I returned' (Il.i.86). Similar to John Smith in Proceedings of the English Colony, Albert is shown as able to manage his appetites - for sex, food, and sleep - in ways that many of the other male French characters in the play find impossible. ${ }^{15}$ The control of appetite, then, is shown to be a significant indicator in the effective performance of manhood. $^{16}$ Just as Edmund Spenser in Book 2 of the Faerie Queene (1590) celebrated restraint and deferred gratification in 'The Legend of Sir Walter, or of Temperance', here Albert's abstinence marks him as superior to his compatriots. $^{.7}$

This scene represents a crisis in the performance of appropriate gender roles for the two main characters. Both Aminta and Albert behave in ways that, at

15 On Smith's ability to control his appetite, sce Mary Fuller, Voyages in Print: English Travel to America (Cambridge: Cambridge University Press, 1995), pp. 85-140.

16 See Anthony Fletcher, "Manhood, the Male Body, Courtship and the Household in Early Modem England', History, 84 ( 1999), pp. 419-436.

17 On the connections between temperance, continence and gendered behaviour, see Louis Montrose, "The Work of Gender in the Discourse of Discovery', Representations, 33 (1991), pp. 1-41 (pp. 11-12). 
times, defy accepted gender indicators. Neither character is able to rest secure in conventional gender performance in the hostile and difficult to understand colonial environment where European rules of conduct must be adapted to meet the needs of new situations. The fact that Albert automatically believes the noise he hears across the water is made by men rather than women - he's proved incorrect almost immediately - reveals the way in which colonists' expectations conceming what they would find were constantly challenged by their actual experiences. When he stumbles 'staggering and collapsing' onto the Portuguese women's island, Albert is unable to distinguish between fantasy and reality, questioning whether he is still alive, 'Do I yet live?' (II.ii.73) or has arrived in the Elysian fields of classical tradition, before constructing the women as 'goddesses' (II.ii.81). Albert cannot make sense of his environment and, as a consequence, understands the Portuguese women through the filter of an earlier set of beliefs. ${ }^{1 k}$ His views reveal him to be noble since they show his classical learning but, just as the epithet plus ultra encapsulated contemporary ambitions to go beyond the knowledge of the ancients, Albert here needs to develop new ways of confronting, understanding and controlling new experiences. ${ }^{19}$ The Pillars of Hercules represented the limits of classical wisdom, and just as explorers and empiricists literally and metaphorically attempted to sail beyond ancient boundaries, here Albert must look beyond classical models in order to understand that the women are in fact Portuguese castaways merely mimicking Amazonian practices. His identification of the women as 'nymphs of Dian's train' (II.ii.83) is, of course, partly explained by the appearance and demeanour of the women, since Rosellia, finding herself, her daughter and her servants isolated from their menfolk, has revived an Amazonian way of life. Like Albert, the Portuguese women have reverted to fabled ancient ways of life which, through the development of hunting skills, have enabled them to survive in the short term. But the all-female colony faces a serious problem that, unjess it is resolved, will extinguish the group over time. Both the Amazonian women and Albert are only partially supported by the text as all are, with gentle humour, shown to be erring in some way. No one reveals him-or-herself to be able to either understand, or to adapt successfully and in sustainable ways to the environment.

18 In the previous scene, Albert on first seeing Sebastian and Nicusa had thought that they were 'wand'ring shadows', or ghosts (I.iii. 104-6).

19 On the implications of the popular phrase plus $u$ tra at this time see John Steadman, 'Bcyond Hercules: Francis Bacon and the Scientist as Hero', Studies in the Literary Imagination, 4 (1971), pp. 3-47. 
In fact Rosellia is facing both rebellion from her band of women who, increasingly dissatisfied with their chaste existence find their only relief in erotic dreams ('For if I have any pleasure / In this life but when I sleep, I am a pagan' II.ii.43-44), and destruction from the fact that without offspring her colony will inevitably die out. Albert, although he had intended to secure himself a share of the hunters' victuals, finds himself to be the women's prey. Besieged by the women's obvious sexual frustration and anxious to find food for 'a virgin almost pined' (II.ii.249), Albent cannot acknowledge Aminta as anything more than a sister and lies to Clarinda's direct question 'She's not your wife?' (II.ii.250), promising to ignominiously 'live your slave' (II.ii.257) if Aminta's hunger is relieved. Rosellia and her followers have -- the text encourages us to believe - appropriated a way of life that is doomed to failure and, moreover, one that forces Albert to lie dishonourably concerning the real nature of his relationship with Aminta.

Native inhabitants are only directly mentioned in one context in The Sea Voyage. Rosellia, the leader of the shipwrecked Portuguese Amazonian women, in order to persuade the others to continue to shun men, describes how their present lifestyle imitates that of the previous inhabitants: 'this blest place' she says was 'inhabited heretofore by warlike women / That kept men in subjection" that have since died out (1l.ii.196-198). The erasure of troublesome natives in the text is particularly topical since the play was first performed in the wake of the massacre of approximately 347 Jamestown colonialists by a confederation of tribes marshalled by chief Opechancanough on the morning of 22 March 1622 . According to Edward Waterhouse's 1622 A Declaration of the State of the Colony in Virginia this 'divellish murder' was achieved through 'treacherous dissimulation' on the part of the native Americans. ${ }^{20}$ Though Company instructions of

20 As critics such as Peter Hulme, Stephen Greenblatt, and Mary Fuller have argued, in the wake of this native violence, the colonialists felt licensed to undertake the violent 'conquest' of indigenous inhabitants 'by force, by surprize, by famine in burning their Come, by destroying and burning their Boats, Canoes, and Houses, by breaking their fishing Weares by assailing them in their huntings', rather than continuing with the much more onerous policy of encouraging 'civilitie ... the effect of long time, and great industry'. See Edward Waterhouse, A Declaration of the State of the Colony in Virginia (London, 1622; repr. New York: Da Capo 1970), p. 13, p. 24; Peter Hutme, Colonial Encounters: Europe and the Native Caribbean (London \& New York: Routledge, 1986), pp. 136-173; Fuller, Voyages in Print, pp. 85-140; Stephen Greenblatt, 'Invisible Bullets: Renaissance Authority and its Subverion', in Political Shakespeare: New' Essays in Cultural Materialism, ed. Jonathan Dollimore and Alan Sinfield (Manchester: Manchester University Press, 1985), pp. 18-47. 
24 July 1621 encouraged colonists to cement friendly relations with native Americans by allowing them into their settlements, policies of cultura! accommodation were ended after the massacre. Given the crisis such news provoked for the fortunes of the Virginia Company, and also given, as Gordon McMullan argues, that it is likely Fletcher was a shareholder in the Company in 1620 at least, it is no surprise that The Sea Voyage, first performed in June of 1622, balks at the direct treatment of such subject matter. ${ }^{21}$ It was not until 1623 that a play, A Tragedy of the Plantation of Virginia (now lost), was performed at the Curtain which focused on the massacre, though direct responses to the calamity can be found in John Donne's sermon preached to members and friends of the Virginia Company on 13 November 1622 and in his friend Christopher Brooke's 'A Poem on the Late Massacre in Virginia'. Brooke's poem concentrates on the depraved nature of the Indians: they are "the very dregs, garbage, and spawne of Earth' and he calls for their complete annihilation. ${ }^{22}$ Donne's sermon, though less explicitly blood-thirsty, is concerned with an English evangelical mandate to spread the word of God among heathen peoples that simultaneously argues for native American dispossession under the Roman Law argument known as res nullius. ${ }^{23}$ According to this argument, the (Christian) colonist is obliged to make all arable land productive: hence, the removal of a people that fail to fulfil this responsibility is justified as long as it is placed in the hands of others who do not allow it to go to waste:

2I Sce Gordon McMullan, The Politics of Unease (Amherst: University of Massachusetts Press, 1994), pp. 235-256. For an altemate reading, anguing against reading The Sea Voyage against a Virginian context sce Michael Neill, Putting History to the Question: Power, Polinics and Society in English Renaissance Drama (New York: Columbia University Press, 2000), pp. 312-315.

22 Quotation taken from Walter S. H. Lim, The Arts of Empire: The Poetics of Colonialism from Ralegh to Milton (London: Associated University Presses, 1998), p. 73.

23 For further details concerning colonists" moral obligation to dispossess those that failed to make a landscape yicld its full potential, see Anthony Pagden, 'Dispossessing the Barbarian: The Language of Spanish Thomism and the Debate over the Property Rights of the American Indians', in The Languages of Political Theory in Early-Modern Europe, cd. Anthony Pagden (Cambridge: Cambridge University Press, 1987), pp. 79-98. 
In the Law of Nature and Nations, A Land never inhabited, by any, or utterly derelicted and immemorially abandoned by the former Inhabitants, becomes thejrs that wil posesse it. So also is it, if the inhabitants doe not in some measure fill the Land, so as the Land may bring foorth her increase for the use of men: for as a man does not become proprietary of the Sea, because he hath two or three Boats, fishing in it, so neither does a man become Lord of a maine Continent, because hee hath two or three Cottages in the Skirts thereof. ${ }^{24}$

However, the convenient emptying out of the colonial terrain of its native inhabitants and their replacement with a different Other, European women, is significant in The Sea Voyage. Following the Virginia massacre of 1622, the disappearance of natives from colonial landscapes is a powerfully seductive fantasy as it, of course, immediately solves what has become a deeply problematic relationship. In The Sea Voyoge, then, European women occupy the space in which colonists would expect to find native inhabitants. Thus the threatening force of a native population is textually contained through their absence, and a more palliative substitute, European women, put in their place. Just as Pocahontas represented for male English colonists a heady blend of exotic race and different gender, so European women's appropriation of titillating Amazonian behaviour represents an equally potent fantasy. ${ }^{25}$ The distrust with which English colonists now viewed Algonkian Indians is displaced onto Rosellia and her band at the same time as their erotic appeal and reproductive capacities mean that, unlike native Americans, they will ultimately be assimilated rather than annihilated. For example, Rosellia shows some familiarity with the sexual practices of the fabled Amazons since, when her women persist in their desire to have traffic with men, she suggests the following 'resolution':

24 John Donne, 'A Sermon Preached to the Honourable Company of the Virginian Plantation', in The Sermons of John Donne, ed. Evelyn M. Simpson and George R. Potter (i0 vols., Berkeley and Los Angeles: University of Califomia Press, 1953-62), vol. 4, pp. 264-82 (p. 274).

25 On the significance of Pocabontas, see Philip Barbour, Pocahonsas and her World (Boston: Houghton Mifflir, 1970); Fuller, Voyages in Print, pp. 120-122; Hulme, Colonial Encounters, pp. 143-147. 
If you like their persons

And they approve of yours - for we'll force nothing,

And since we want ceremonies, each one

Shall choose a husband, and enjoy his company

A month, but that expired you shall no more

Come near "em. If you prove fruitful

The males ye shall return to them, the females

We will reserve ourselves.

(1I.ii.234-241)

This is a dilute version of Amazonian practices since, where Amazons were believed to violently kidnap their partners or even mutilate them to make them more amenable to their advances, here no "force" will be used. ${ }^{2 t}$ Amazonian brutality is curbed because, in the aftermath of the Virginia massacre, threats of direct violence would make the eventual reassimilation of the women more difficult. Intensely aggressive European women would appear too much like the natives they simultaneously mimic and replace, and would, like them, have to be destroyed. Fletcher's representation straddles uneasily the ambivalence of Otherness as seductively exotic and violently threatening. Indeed, Stephen Greenblatt sees this conflation of desire and violence as symptomatic of European relations with the New World: 'Europeans destroyed Indian culture not despite those aspects of it that attracted them but in part at least because of them'. ${ }^{27}$ After the Virginia massacre, as Waterhouse's comments starkly reveal, colonists were licensed to annihilate native Americans 'by pursuing and chasing them with our horses, and blood Hounds to draw after them, and Mastives to teare them'. ${ }^{2}$ White women, even as they appear in lieu of natives, in order not to suffer the same fate as the now extinct original native inhabitants, must remain recognisably European. They simulate natives, but must remain sanitised versions; to 'go native' fully would result in the violent treatment Waterhouse recommends. In The Sea Voyage the women must not demonstrate violence too explicitly, since it will inevitably escalate beyond their control until, like Waterhouse's plan, a

26 Michel de Montaignc, for example, described the way 'Scythian women were wont to thrust out the eies of all their slaves and prisoners taken in warre, thereby to make more frec and private use of them', Essays, trans. J. Florio, intro. L. C. Harmer (London: Dent, 1965), pp. 91-92.

27 Stephen Greenblatt, Renaissance SelfFashioning: From More to Shakespeare (Chicago \& London: University of Chicago Press, 1980), p. 183.

28 Waterhouse, A Declaration of the State of the Colony in Virginia, p. 13. 
sustained policy of extermination is put into practice. The violent yet paradoxically 'civilising' forces of European patriarchy and colonialism will not allow subordinate groups - indigenous peoples and women - to use aggression more successfully than they do. In other words, the odds are stacked in favour of colonial/patriarchal authority since it has determined the rules of the game and has the best equipment: guns beat bows and arrows. Colonial/patriarchal discourse thus constructs natives/women as inexplicably violent or unruly in order to be able to control them all the more successfully through increased levels of violence, and, simultaneously, justifies the use of such violence. In the face of what Waterhouse called the Algonkian's 'treacherous dissimulation', English colonists needed to be ever vigilant. Female/native violence hence remains a threat in The Sea Voyoge because it is - paradoxically - necessary to colonial/ patriarchal discourse. Rosellia's Amazonian customs may, at any time, descend into savagery: hence there is the ever-present erotic prospect that male (sexual) control through violence will need to be exerted over the band of women.

The text's difficulties with female/native violence explains Rosellia's claims that the temporary nature of the couplings is motivated by a lack of 'ceremonies' (Il.ii.236), or civilised religious marriage practices, on the island. Such a description shows that she is implicitly comparing island practices against European ones: Europe is still the measure of civilised behaviour, the women are only pretending to be Amazonian, their efforts here are ridiculous and grotesque rather than so threatening and violent that they must be killed. Consequently, Fletcher and Massinger make much of the humour of the community of women's discontent with their sexual isolation as well as of the ironies of Rosellia's woefully misguided appropriation of the practices of a dead civilisation. Similarly, when Rosellia agrees to sexual commerce between her women and the French, her innately European mindset is shown by the way she gives the men their choice, abdicating from the patriarchal position of disposer of females in marriage (III.257-262); and when complimented by Tibalt and singled out as his choice of partner, she appears flattered and pleased (III.310335). Rosellia's Amazonian practices, then, are bluff and bluster: she remains firmly within a European frame of reference.

The play wittily engages with the notorious difficulties of survival for Europeans in colonial locations. Specifically it focuses on the difficulties of maintaining adequate supplies of food and the need to ensure that colonists are able to breed and produce new generations. Fletcher and Massinger persistently link these two issues together. Starvation is an ever-present threat as, for example, 
hunger forces the French gallants to contemplate eating both the unpleasant detritus of the landscape and, more importantly, the only woman that they number amongst their band at this point. In a parody of the blazon - which, as Nancy Vickers has shown, was thoroughly inscribed in commercialism as it displays and merchandises a female body for other men - the French discuss the attributes of their female quarry before agreeing to 'divide her, every man his share.' (III.112) ${ }^{29}$ The men's plot to eat Aminta is explicitly described in sexual language as they all wish to consume her 'hinder parts' (III.132) in particular. When Tibalt and the Master of the ship discover the gallants' scheme they initially think that the plan is one of ravishment (III.146). The Frenchmen confess to an 'appetite' (111.150), and Tibalt suddenly realises that their desires are in fact cannibalistic. With grotesque humour, he shows the folly of the gallants' desires. He sarcastically represents himself as being more dismayed at the thought of eating women than raping them as he violently chastises the men: 'Are ye so sharp set that her flesh must serve you'? and 'why did you not / Begin with one another handsomely, / And spare the woman to beget more food on'? (III. 151-156). In these exchanges it is not ideas of rape or cannibalism that are the focus of Tibalt's sarcasm. He advocates that Aminta be spared in the hope that she will prove fertile, and her consent to such congress is immaterial. Furthermore, his reaction to the notion of cannibalism is also gender specific: it is the senseless stupidity of eating the only woman in the group that is the crux of the sarcasm. In a survival-driven economy Aminta is important as the mother of future generations and the men are threatening to destroy what they most need, European women. There is a painful and horrible logic to Tibalt's reasoning here that would not be lost on a London audience in 1622 who would know about the outbreak of wife-murder and cannibalism amongst Jamestown colonists in the starving time of 1609-10."

29 The blazon is the rhetorical equivalent of the display and merchandising of the female body, deployed within a triangulated discourse in which a male seller praises his female wares to a potential male buyer. See Nancy Vickers, "'The blazon of sweet beauty's best": Shakespeare's Lucrece', in Shakespeare and the Question of Theory, ed. Patricia Parker and Geoffrey Hartman (New York: Methuen, 1985), pp. 95-115. See also Joan Pong Linton, The Romance of the New World: Gender and the Literary Formations of English Colonialism (Cambridge: Cambridge University Press, 1998), pp. 104-130.

30 See Maggie Kilgour, From Communton to Cannabalism: An Anatomy of Metaphors of Incorporation (Princeton: Princeton University Press, 1990), pp. 3-19. Sce also Claire Jowitt, 'Colonialism, Politics and Romanization in John Fletcher's Bonduca', SEL, forthcorning 2002. 
Tibalt here is parodying the merchants and gallants by sarcastically advocating that they follow the most horrific form of food production possible, the eating of their own babies. Through Tibalt, Fletcher takes the cannibalistic metaphor to its most horrific literal extreme.

The stupidity of the French gallants' cannibalistic desires directly parallels the situation of Rosellia's misguided Amazons who, if they pursue their avoidance of sexual congress, will inevitably become extinct. Rosellia's policy represents a distorted and unnatural form of female behaviour in the world of the play: Crocale, Hippolita and Juletta represent their isolation from men as 'more than tyranny' (II.ii.23) since it forces them to be less than full women. In The Sea Voyage women are judged by their heterosexual activity and are described as sexual objects to be consumed by men. As a corollary to this, then, the Frenchmen's cannibalism represents a failure of commercialism since cannibalism - as the direct or physical incorporation of the desired object - is an act that precludes any future communion with that desired object. ${ }^{31}$ The men's intention to eat Aminta is hopelessly inadequate not only because it is cannibalistic but also because it fails to treat women and their offspring as important and sustainable resources. Cannibalism here represents commercial deficit and Fletcher's French gallants - unlike Tibalt and Albert - stand for those colonials who fail to understand that survival is only ensured through the correct husbandry of resources. Through wishing to eat female flesh, Fletcher represents the Frenchmen as unmediated consumers and that makes them the wrong kind of consumer. This failure is also gender specific. It represents the Frenchmen as inadequate males who, in contrast to Albert and Tibalt, cannot control their. appetites or, more correctly, possess the wrong appetite. To put it crudely, these men desire to eat women rather than have sex with them and consequently reveal themselves to be inferior males. The grotesque humour does not, of course, advocate 'rational' cannibalism. Rather cannibalism - an index of savagery - is here used to differentiate between male colonial leaders and those colonists that are meant to be subordinate.

In The City Madam too, the male characters" attitudes to women - and the sorts of appetites they demonstrate - are key indicators of their self-mastery and internal discipline, in other words, of their effective masculinity. The planned treatment of Lady Frugal and her daughters is a case in point. The punishment

31 Kilgour, From Communion to Cannabalism, pp. 17 19. 
Sir John describes is, importantly, not meant to be carried out: he only wants to threaten his wife with death not actually have her murdered. Massinger draws a distinction between the threat of violence against women and the reality of murdering them. The former, since it is a policy endorsed and created by Sir John, is clearly supported in this text as a useful disciplinary tool: it is a form of social control. Similarly the male fantasy of murdering one's wife - as long as one doesn't actually do it - is represented positively by Massinger since it serves as a safety valve for male aggression against unruly women. Sir John, Plenty and Sir Maurice's collective fantasy of sending their womenfolk to New World death paradoxically allows them to live successfully with women in the Old World as, for the men, images of violence against women in America neutralise their aggression in Britain. Luke's eagerness to make the threat real, though, is represented as morally reprehensible. Luke's appetite for money is so intense and uncontrollable that he will sell his nearest female relations into, he believes, their certain death at the hands of native Americans. He is prepared to betray his race and nation for money and enter into the wrong sort of trade with a savage and inferior people: his trafficking in British women with indigenous American men undermines a colonial nation's innate sense of superiority. Hence, Luke's projected despatch to Virginia in the final scene is fitting and appropriate since he has, through his anti-English trading policies, symbolically already deserted his own culture (V.iii. 134, 144). Similar to the French gallants in The Sea Voyage, only in less obvious ways, Luke is an inadequate male. But whereas Franville, Morillat and Lamure are inadequate in terms of their failure to understand the most basic economic principals (sound businessmen eat the profits not the capital), Luke fundamentally betrays British colonial ambitions since they were predicated and justified through beliefs in the superiority of white men over black men which were, in turn, predicated on the exclusive sexual access of white men to white women. When John Rolfe married Pocahontas in 1614, the bridegroom was clearly exercised concerning the difficulties of miscegenation through 'marrienge of strange wyves'. ${ }^{32}$ But at least such a union marked, as Rolfe argued, 'the converting [of] an irregenerate to a regeneration' and, significantly, the relationship did not trouble gender hierarchy since an inferior woman was

32 'Copy of John Rolfe's Letter to Sir Thomas Dale Regarding His Marriage to Pocahontas', in Barbour, Pocahontas and her World, p. 247. 
embracing the culture of her superior husband. ${ }^{3}$ Luke's sale of his female relatives to savage, devil-worshipping native Americans betrays his religion, his culture and his gender. His interests should be, like his brother's, in the conversion of heathen peoples, the commercial exploitation of America through legitimate trade, and, as patriarch, the protection of his female relatives. Luke's appetite for money, then, is unrestrained. As John Locke sums up in his treatise of 1693 on the bringing up of boys, a proper man must 'get a mastery over his inclinations and submit his appetite to reason', and Luke signally fails to exercise such selfdiscipline through his greedy desires to 'surfeit in my store' (V.i. 146). ${ }^{34}$

The distinction drawn between men who can and men who cannot control their appetites in these two plays is not simply based on class. The way control of appetite rather than social position determines effective masculinity is particularly strikingly revealed in The Sea Voyage when Tibalt takes control of the parcelling out of the women in Act III, telling the gallants and merchants to 'Stand back and give your betters leave, your betters, / And grumble not' (268269). His superior strength of character, demonstrated by his sustainable sexual appetite for women, allows him to take command over men that prior to the shipwreck had been richer or of equal or higher rank (I.ii.115-148): it is in this sense alone that he is their 'better'. This moral hierarchy contrasts to the situation in Virginia in 1609 when John Smith contemplated breaking the ties with the Company's London headquarters. New officers of higher social standing than himself were appointed, leading to repeated stand-offs between the experienced Smith and the new arivals, so that Smith wished that the new men 'had never arrived, and we for ever abandoned and left to our fortunes' ${ }^{35}$ Indeed, similar to Virginia under the stringent control of the 1610 Lawes Divine, Moral and Martial which were designed to make the colonists work in tandem, in The Sea Voyage all the factions in the play - Sebastian and Nicusa, Rosellia and the women, and the shipwrecked French - have no possible future unless

33 Philip Barbour, The Three Worlds of Captain John Smilh (London: Macmillan, 1964), p. 329.

34 Cited by Anthony Fletcher, "Manhood, the Male Body, Courtship and the Household in Early Modern England", p. 423.

35 John Smith, Travels and Works of Captain John Smith, ed. Edward Arber and A. G. Bradley (Edinburgh: John Grant, 1910), p. 479. 
rapprochement is achieved. ${ }^{36}$ The fact that hamnony is needed to make survival a possibility in colonial locations becomes, as we shall see, the reason why in the last scene all the colonists can finally forgive each other, even the French gallants and Rosellia, for the violence threatened against them.

The text continually represents the characters retreating into sleep or fantasy since the reality of colonial life is a nightmare. The Amazonian women have erotic dreams as their escape from sexual frustration, and Aminta is counselled by Albert to sleep while he tries to find food for them promising that in her dreams she will be able to imaginatively recreate herself as 'a queen' sponsoring his mission of discovery of a 'fortunate continent' (11.i.92-93). Sleep is thus represented as a way for the characters to recreate their environment according to colonial fantasies of ease and abundance. Yet, the wisdom of such a retreat from reality is consistently questioned by the text. Albert faints through pain and exhaustion, but when he comes round he is so disorientated that he is unable to distinguish fantasy from reality. His questioning of the status of the women he sees on regaining consciousness shows him to be in a liminal state between real and imagined worlds. His subsequent loss of integrity through his denial of Aminta and his promise to be a subservient 'slave' to Clarinda further reveal the dangers of fantasy. Indeed, Aminta's sleep makes her vulnerable to the cannibalistic desires of her compatriots. She asserts that 'sleep is a salve for misery' (III.iii.75), yet the men see her sleep as further insult: 'Why should she have this blessing / And we wake still, wake to our wants?' (III.iii.78-79). The pleasure of sleep and its status as safe retreat from present miseries is challenged. Furthermore, when she wakes, she is aware that she has experienced a nightmare ("What cruel dreams have I had') but is unable to understand that this is a reflection of current danger as she believes the French men are no threat to her: 'Who are these? / O they are my friends!' (III.iii.]14-115).

Sleep, then, is represented in The Sea Voyage as a dangerous phantasm into which characters retreat when their circumstances become too difficult to confront. Though supposed to offer an escape from reality, unconsciousness in fact compounds the situations in which characters find themselves. The seductive fantasy of a sensual New World Paradise so optimistically articulated in

36. Lawes Divine, Morall and Martiall, in Tracts and Other Papers Relating Principally to the Origin, Settement and Progress of the Colonies in North America, ed. Peter Force (4 vols., Gloucester, Mass: Peter Smith, 1963), vol. Ill. 
contemporary promotional texts and which, in different ways, all the characters expect to find, has, to quote Anthony Parr, gone 'sour '. ${ }^{37}$ The French gallants expect to inhabit 'happy places and most fertile islands / Where we had constant promise of all things' (111.83-84) in the same way that, for example, Arthur Barlow's description of the first Roanoke voyage imagined that the colonial landscape would yield 'all things in abundance, as in the first creation, without toil or labour'. ${ }^{58}$ Arcadia, or a munificent paradisiacal landscape, is a phantasm: the New World Eden is full of unexpected pitfalls. ${ }^{39}$

The concluding scene in The Sea Voyage, where heterosexual relations are resumed and, superficially at least, all misunderstandings resolved, show the characters finally confronting the realities of their situation. However, before the denoucment, horrific tragedy is only narrowly averted. Rosellia discovers that Aminta's and Raymond's, as well as Albert's, fathers were responsible for originally dispersing the Portuguese and then attacking again to wrest from them 'the last remainder of their wealth' (V.ii.96). She resolves to take her revenge and plans to execute the children of the men who caused her misfortune. Rosellia here prepares to sacrifice the French in a frenzied manner. She requests "Infernal music, / Fit for a bloody feast' (V.iv.2), and commands 'Set out the altar. I myself will bc / The priest, and boldly do those horrid rites / You shake to think on' (V.iv.8-10). Rosellia also refuses to listen to good counsel. She insists on avenging the death of her husband through the execution of the children of his alleged murderers even though such actions are unjust because Sebastian still lives (V.iv.50-55). It is only the Portuguese men's entrance in the nick of time that prevents Rosellia's murderous revenge. The distnust between the French and the Portuguese is of such a pitch that Rosellia disbelieves everything her enemies say, preferring to act according to savage customs: for the first time Rosellia appears more savage than European. Rosellia's aggression and her violent threats mark her out as unacceptably Other both in terms of her gender and racial

37 Parr, 'Introduction', p. 25.

38 'Arthur Barlowe's Discourse of the First Voyage,' The Roanoake Voyages, 1584-1590, cd. D. B. Quinn (2 vols., London: Hakluyt Society, 1955), vol. I, p. 108.

39 See Erwin Panofsky. 'Et in Arcadia Ego', Philosophy and History, ed R. Klibansky and H. J. Paton (New York: Harper \& Row, 1963), pp. 223-254; see also Michael Luckeman, 'Identity in British America: Unease in Eden', in Colonial Identity in the Allantic World. 1500-1800, ed. Nicholas Canny and Anthony Pagden (Princeton: Princeton University Press, 1987), pp. 115-159. 
behaviour since she is treacherous and unruly, yet she is not punished for these transgressions. Once her husband reappears, Rosellia immediately reverts to subservient female behaviour. She quickly abdicates 'those arts not usual to our sex' (V.iv.4l), and gives up 'Herself, her power and joys and all to you, / To be discharged of 'em as too burdensome' (V.iv.96-97), and yet nothing further is said or done about her. Given the Virginia massacre, and the violent responses it generated in commentators such as Waterhouse and Brooke, we need to explore why Fletcher's and Massinger's text chose to be so restrained in its treatment of the woman who stands in for native inhabitants in the play?

There are two ways of reading this restraint. The first is that the central concern of the text has been to show that enmity between factions destroys colonial futures. The raw material from which new colonies are to be fashioned is not promising in The Sea Voyage. As the barren nature of Sebastian's and Nicusa's land reveals, the terrain is often inhospitable, and the settlers were, more often than not, a feckless and inadequate lot. Lamure, Franville and Morillat signify the recalcitrant and unruly wastrels who made up a large proportion of New World colonists. As Nicholas Canny has argued, 'a majority of those who took ship to Virginia were making the final of a series of moves in an unsettled and rootless existence' ${ }^{\prime \prime}$ And, as we have seen, in terms of commercial sense, Lamure, Franville and Morillat are spectacularly incompetent since they plan to eat the only female in their group rather than husbanding her as a sustainable resource. Rosellia and her women represent simultaneously both European women and native inhabitants. And though racial and sexual Others, they are necessary for the colony's future. The women figure as textual traces for native inhabitants, whom British colonists might imagine did not exist, or, following Brooke and Waterhouse, wish had been annihilated. But, by representing native inhabitants as fernale, and emphasising how reproduction was necessary for any colony's future, Fletcher and Massinger reveal that native help and women are both essential to successful colonisation. Just as Prospero was shown 'all the qualities 'o'th'isle' (I.ii.327) by Caliban in The Tempest, and hence survived shipwreck in an unfamiliar world, native Americans are still going to be needed by the Jamestown settlers even after the Virginia massacre." Brooke and

40) Nicholas Canny, 'The Pernissive Frontier', p. 29.

4] William Shakespeare, The Tempest, ed. Anne Barton (Harnondsworth: Penguin, 1968). 
Waterhouse fantasised about their extermination, Donne and Purchas created moral and legal justifications for dispossessing native Americans, but throughout the $1620 \mathrm{~s}$ and well into the $1630 \mathrm{~s}$ English colonies in North America were not self-supporting. However unpalatable her violence, Rosellia's reabsorption shows that European women and native peoples were essential, for their reproductive capacities and access to food resources, for the survival of the colony.

Secondly, this play can be read as deeply uncertain about colonial futures. The final rapprochement between characters and separate groups of colonists is achieved incredibly swiftly in the final scene of The Sea Voyage: after Rosellia's sacrificial oblations there are only fifty lines in which Clarinda and Raymond, Crocale and Tibalt, Aminta and Albert, Rosellia and Sebastian all pair up, and amity is finally achieved between the previously competitive French and Portuguese colonists. The tension created by Rosellia's extreme violence so near to the end of the play simply does not have enough time to disperse. The horror in which her actions so nearly resulted cannot be contained within so short a space of time. The unsettled nature of the text's conclusion is similarly shown by the fact that the final lines are not concemed with the future of the islands on which these colonists have been shipwrecked. Rather, as Sebastian states, "When awhile / We have here refreshed ourselves, we'll return to our several homes' (Viv. 10-112). It appears that the hard-won understanding that has been achieved between the French and Portuguese by the end of The Sea Voyage will not result in the development of a joint French and Portuguese colony that might avoid the endemic factionalism and competition that has plagued the characters throughout the course of the play. The French and the Portuguese might, the text tells us, once more be 'friends', but that understanding does not result in a lasting joint colony where resources would be pooled.

The conclusion of The Sea Voyage is uncertain in tone. Throughout the course of the play, we witness the misunderstandings and competitive rivalry between groups of people that need to be overcome to create a hamonious and tenable colonial future. However, at the moment in which such a positive outcome becomes, for the first time, a real possibility, it becomes clear that there is, in fact, no future for this embryonic Portuguese and French colony. As soon as the colonists are able, they intend to abandon the islands and return home. How should we read the conclusion then? The painful seasoning that the colonists have experienced appears, at the very end, utterly pointless in terms of securing lasting colonies. Perhaps the newly created Portuguese-French alliances will pay dividends in future jointly inspired endeavours, but we are given no hint by the 
text that such missions are planned. Instead, despite the ostensible happy ending, a lot of hard work and suffering has occurred to achicve nothing in terms of colonial success. Of course, the fact that it is French and Portuguese colonists that abandon the islands might be seen to some extent to ameliorate this anticolonial reading since supporters of British colonies could take satisfaction in the failure of their Furopean rivals. The play's emphasis, though, on the need for understanding and co-operation between Furopean competitors complicates any straightforward reading of the text as either praising British endeavour or supporting British territorial claims through French and Portuguese colonial failure. Indeed British exclusion from the colonial terrain this play describes might be seen as an indictment since the British have failed to secure New World territory in the way that other Furopean nations had. As Francis Bacon enviously commented in 1622, the lberians possessed an empire on which 'the sun never sets' ${ }^{42}$ Consequently the contemporary crisis in British colonialism is implicated in several ways in this play. The French and Portuguese fail in the play, as the British have done in 1622 Virginia, to harness tangible benefits from their New World experiences even though the most immediate indicator of that crisis native peoples '. are partially tamed through their incarnation as assimiliable Furopean women. But, at the same time, the fact that the English are absent from the colonial terrain of the play's world while other nations are present can be seen, as Jeffrey Knapp argues more generally, as an indictment of the signal failure of British colonial policy at this time. ${ }^{43}$ French and Portuguese might not be successful, but in 1622 the British are not even there.

By contrast, in Massinger's 1632 The City Madam the casual and matter of fact references to the Virginia colony show the much more established nature of the settlement. Britain has a clear presence in the New World. Yet, problems with the colony are still apparent. Sexual licentiousness is represented as endemic, and Sir John's descriptions of indigenous Americans' desires for white women reveal the level of anxieties conceming miscegenation and the threat that black male sexual access to white females represents to British males. Indeed, in these two dramas sexual appetite is used to measure commercial success and effective

42 Francis Bacon, Advertisement touching an Holy War, in Works of Francis Bacon, ed. J. Spedding et al. (14 vols., London: Longman and Co, 1857-1874), vol. VII, pp. 20-21.

43 Jeffrey Knapp, An Empire Nowhere: England, America and Literature from Utopia to The Tempest (Berkeley: University of California Press, 1993). 
masculinity. Gender is as much of a commercial resource as any other New World commodity and its proper manipulation is the central concem of these dramas. Fletcher and Massinger reveal the continued problems of English colonialism at this time, which needs the endeavours of appropriately masculine men such as Tibalt, Albert or Sir John. In order to be successful English colonialism needs men that both demonstrate the correct appetite and are simultaneously able to control their desires. The Sea Voyage and The City Madam function, then, as an indictment against British colonialism since Tibalt and Albert are French and Sir John exists in an Old World setting: neither of these plays represent potent British manhood in the New World.

Department of English University of Wales Aberystwyth

For helpful comments and discussion about this article I am grateful to Ruth Gilbert, Andrew Hadfield, Greg Walker, Theresa Walters, and Diane Watt. 